JURNAL
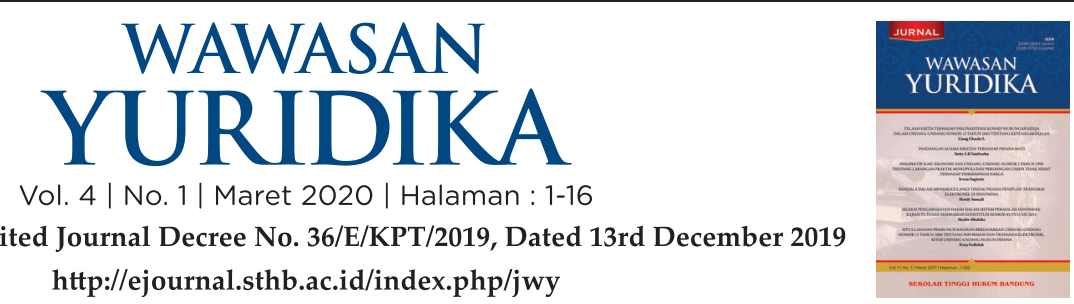

Nationally Accredited Journal Decree No. 36/E/KPT/2019, Dated 13rd December 2019

http://ejournal.sthb.ac.id/index.php/jwy

\title{
Kebijakan Corporate Social Responsibility (CSR) sebagai Strategi Hukum dalam Pemberdayaan Masyarakat di Indonesia
}

\author{
Hari Sutra Disemadi ${ }^{1}$, Paramita Prananingtyas ${ }^{2}$ \\ ${ }^{12}$ Fakultas Hukum, Universitas Diponegoro, Semarang, Indonesia \\ $\triangle$ Corresponding Author: haridisemadi@gmail.com
}

\section{Info Artikel:}

DOI: $10.25072 /$ jwy.v4i1.328

Diterima: 9 Januari 2020 I Disetujui: 17 Maret 2020 | Dipublikasikan: 25 Maret 2020

Kata Kunci:

Corporate Social

Responsibility; Kebijakan Hukum; Pemberdayaan Masyarakat.

\begin{abstract}
Abstrak
Pembangunan berkelanjutan (sustainable development) dimaksudkan agar perusahaan mensinergikan aspek keuntungan (nilai ekonomis) dengan aspek lingkungan, serta aspek sosial seperti pemberdayaan masyarakat. Penelitian ini bertujuan untuk mengetahui kebijakan pengaturan tanggung jawab sosial dan lingkungan oleh perusahaan di Indonesia sebagai strategi pemberdayaan masyarakat. Penelitian ini bersifat deskriptif dengan jenis penelitian hukum normatif. Penelitian ini menunjukkan tanggung jawab perusahaan terhadap aspek sosial dan lingkungan dilakukan dengan pelaksanaan corporate social responsibility (CSR). Konsep CSR di Indonesia telah memperoleh legitimasi hukum untuk dilaksanakan oleh perusahaan swasta maupun badan usaha milik negara (BUMN). Kebijakan CSR merupakan strategi hukum yang digunakan dalam peningkatan pemberdayaan masyarakat melalui program-program bantuan pendidikan gratis, pelatihan pengembangan usaha lokal untuk membuka peluang usaha bagi masyarakat, serta program kepedulian berupa recruitment tenaga kerja lokal.
\end{abstract}

Keywords:

Corporate Social

Responsibility; Legal Policy; Community Development.

\begin{abstract}
Sustainable development is intended for companies to synergize aspects of profit (economic value) with environment aspects and social aspects such as community empowerment. This study aims to determine regulatory policies regarding social and environmental responsibility by companies in Indonesia as a community empowerment strategy. This research is descriptive research with normative legal research methods. This research shows the company's responsibility towards social and environmental aspects is carried out by implementing corporate social responsibility (CSR). The concept of CSR in Indonesia has gained legal legitimacy to be implemented by private companies and state-owned enterprises (BUMN). The CSR policy is a legal strategy used in enhancing community empowerment through free education assistance programs, local business development training to open business opportunities for the community, and awareness programs in the form of recruitment of local workers.
\end{abstract}




\section{A. PENDAHULUAN}

Hakikat pembangunan adalah proses perubahan yang berlangsung secara terencana, sadar, serta berkelanjutan. Oleh sebabitu, pembangunan merupakan tanggung jawab semua elemen, baik masyarakat, swasta, serta pemerintah. Pembangunan yang berkelanjutan perlu adanya upaya checks and balances, upaya tersebut membutuhkan partisipasi masyarakat dalam hal mengawasi kebijakan pemerintah (mengawasi penyalahgunaan kewenangan), serta partisipasi pihak swasta (perusahaan) dalam mempengaruhi kebijakan yang dikeluarkan oleh pemerintah. ${ }^{1}$ Era pembangunan dewasa ini, menjadikan perusahaan tidak hanya dihadapkan pada tanggung jawab untuk memperoleh keuntungan atau nilai ekonomis, melainkan juga harus memperhatikan aspek-aspek sosial serta lingkungan. ${ }^{2}$ Sinergi ini dikenal dengan pembangunan berkelanjutan (sustainable development). ${ }^{3}$

Berbicara tentang aspek lingkungan tidak lepas dengan sumber daya alam (SDA) di Indonesia. SDA adalah salah satu bagian yang menjadi modal awal dalam pembangunan. Penambangan emas atau bahan galian lainnya yang dilakukan perusahaan merupakan salah satu contoh pemanfaatan SDA. Kegiatan pertambangan yang dilakukan oleh perusahaan ini pada dasarnya memberikan dampak positif ataupun dampak negatif. Dampak positif dari kegiatan ini adalah peningkatan pendapatan (nilai ekonomis), sedangkan dampak negatifnya adalah terjadi penurunan kualitas tanah, kualitas air, pencemaran, ataupun perubahan estetika lingkungan lainnya. ${ }^{4}$ Dengan demikian, sangat diperlukan adanya sustainable development, yang mana SDA yang sangat melimpah wajib dimanfaatkan untuk meningkatkan nilai ekonomis masyarakat dengan memperhatikan kelestarian alam serta keseimbangan lingkungan.

Pembangunan berkelanjutan (sustainable development) seperti disebutkan sebelumnya harusnya tidak hanya mensinergikan aspek keuntungan (nilai ekonomis) bagi perusahaan

\footnotetext{
1 Yuniarti Wahyuningrum, Irwan Noor, dan Abdul Wachid, "Pengaruh Program Corporate Social Responsibility Terhadap Peningkatan Pemberdayaan Masyarakat (Studi Pada Implementasi CSR PT. Amerta Indah Otsuka Desa Pacarkeling Kecamatan Kejayan Kabupaten Pasuruan)," Jurnal Administrasi Publik (JAP) 1, No. 5 (2014): 109-115, http://administrasipublik.studentjournal.ub.ac.id/ index.php/jap/article/view/340, hlm. 109.

$2 \quad$ Ibid.

Ibid.

4 Erwin Syahputra dan Suteki, "Strategi Baru Pengentasan Kemiskinan Melalui Hukum Sebagai Sarana Pemberdayaan Corporate Social Responsibility," Masalah-Masalah Hukum 46, No. 1 (2017): 1-8, https://doi.org/10.14710/mmh.46.1.2017.1-8, hlm. 3.
} 
dengan aspek lingkungan saja, melainkan juga harus mensinergikannya dengan aspek-aspek sosial, seperti pemberdayaan masyarakat. Tanggung jawab perusahaan dalam mensinergikan aspek-aspek tersebut dilakukan dengan kebijakan tanggung jawab sosial dan lingkungan. Tanggung jawab sosial serta lingkungan lebih dikenal dengan istilah corporate social responsibility (CSR).

Konsep CSR muncul di masyarakat Barat (Eropa dan Amerika) pada tahun 1970 dan terus menjadi topik yang hangat untuk didiskusikan. ${ }^{5}$ Namun, konsep ini sebenarnya pertama kali dikemukakan oleh Howard R. Bowen pada tahun 1953 dalam bukunya yang berjudul "Social Responsibilities of the Businessman", yang menyatakan bahwa "Businessmen must follow those lines of action which are desirable in terms of objectives and values of our society". ${ }^{6}$ Secara sederhana, Bowen mendefinisikan CSR sebagai keputusan perusahaan untuk memberikan nilainilai positif bagi masyarakat. ${ }^{7}$ Kemudian pada tahun 1973, melalui Academy of Management Journal, Keith Davis dengan artikelnya yang berjudul "The Case For and Against Business Assumption of Social Responsibilities" menyebutkan "Iron Law of Responsibility: Businesses must behave responsibly or lose the Power and legitimacy granted by society". 8 Secara sederhana, Davis mendefinisikan CSR sebagai usaha ikhlas dari perusahaan untuk menciptakan keseimbangan ekonomi dan keadaan sosial masyarakat yang baik secara bertanggung jawab. ${ }^{9}$

Salah satu kunci hadirnya CSR adalah isu mengenai pentingnya hubungan harmonis antara pihak pemangku kepentingan (stakeholders), serta pihak perusahaan itu sendiri (shareholders). Stakeholders yang dimaksud di sini adalah pihak-pihak yang berkepentingan terhadap keberadaan perusahaan yang mempengaruhi pengambilan keputusan dan kebijakan perusahaan yang akan diterapkan serta pihakpihak yang terkait dampak operasional perusahaan. ${ }^{10}$ Termasuk di dalamnya adalah pekerja, pemasok, pengguna, pemerintah sebagai pembuat peraturan, masyarakat, serta pemilik perusahaan

5 Muhammad Yasir Yusuf, Islamic Corporate Social Responsibility (I-CSR) Pada Lembaga Keuangan Syariah (LKS) (Depok: Kencana, 2017), hlm. 1.

6 Howard R. Bowen dalam Rajiv Kashyap, Raza Mir, dan Ali Mir, "Corporate Social Responsibility: A Call For Multidisciplinary Inquiry," Journal of Business E Economics Research 2, No. 7 (2004): 51-58, https://doi.org/10.19030/jber.v2i7.2902, hlm. 54.

7 Bowen dalam Muhammad Yasir Yusuf, loc.cit.

8 Keith Davis dalam Rajiv Kashyap, RazaMir, dan Ali Mir. op.cit., hlm. 52.

9 Keith Davis dalam Muhammad Yasir Yusuf, loc.cit.

10 Rahmatullah, "Model Kemitraan Pemerintah Dengan Perusahaan Dalam Mengelola CSR: Studi Kasus Di Kota Cilegon," Sosio Informa 17, No. 1 (2012): 36-47, https:/ejournal.kemsos.go.id/index. php/Sosioinforma/article/view/66/36, hlm. 38-39. 
itu sendiri. Hal tersebut diungkapkan oleh William C. Frederick, Keith Davis, dan James E. Post (1988) dalam buku yang berjudul "Business and Society, Corporate Strategy, Public Policy, Ethics". ${ }^{11}$ CSR merupakan bentuk tanggung jawab atau kepedulian perusahaan terhadap lingkungan maupun kepedulian sosial dengan cara melindungi serta memberi kontribusi pada masyarakat di mana perusahaan itu berada. ${ }^{12}$

SalahsatuteoriCSRyang berkembang adalah teori kontrak sosial (social contract theory). Teori ini menjelaskan hubungan antara perusahaan dengan kehidupan serta elemen-elemen sosial. Berdasarkan teori ini, perusahaan mesti bertanggung jawab terhadap masyarakat. Sikap ini timbul bukan hanya karena keinginan yang kuat untuk meraih keuntungan (nilai ekonomis), melainkan perusahaan harus bersikap sesuai dengan persepsi yang diinginkan masyarakat terhadap perusahaan dalam menjalankan bisnis. Sehingga perubahan persepsi masyarakat terhadap perusahaan menyebabkan perusahaan harus menyesuaikan teknis pelaksanaan CSR. Teori kontrak sosial ini menyebabkan CSR tidak mempunyai standar yang sama antara satu kelompok masyarakat dan masyarakat lainnya. Persepsi masyarakat yang berbeda-beda akan menyebabkan konsep CSR berubah kapan saja karena persepsi masyarakat juga berubah-ubah sesuai dengan faktorfaktor yang mempengaruhinya. ${ }^{13}$

Tumbuhnya tingkat kepedulian kualitas kehidupan, lingkungan, dan harmonisasi sosial dapat mempengaruhi aktivitas dunia bisnis dan peningkatan taraf hidup masyarakat. Atas dasar hal tersebut, lahirlah tuntutan terhadap peran perusahaan agar mempunyai CSR melalui peraturan perundangundangan yang ada. Namun, yang menjadi pertanyaannya adalah, apakah konteks pelaksanaan CSR yang telah digariskan oleh undang-undang ini telah berjalan sebagaimana mestinya, ataukah kegiatan CSR menjadi menu wajib bagi perusahaan untuk dilaksanakan berdasarkan kesadaran (di luar kewajiban yang digariskan undang-undang). Kenyataannya, tidak sedikit pelaksanaan CSR masih terkesan asal-asalan serta belum menyentuh kepentingan masyarakat secara optimal. ${ }^{14}$

\footnotetext{
11 Muhammad Yasir Yusuf, loc.cit.

12 Budi Gautama Siregar, "Penerapan Corporate Social Responsibility (CSR) Dalam Pandangan Islam," Juris 14, No. 2 (2015): 135-150, http://dx.doi.org/10.31958/juris.v14i2.303, hlm. 140-141.

13 Muhammad Yasir Yusuf, op.cit., hlm. 10.

14 Marthin, Marthen B. Salinding, dan Inggit Akim, "Implementasi Prinsip Corporate Social Responsibility (CSR) Berdasarkan Undang-Undang Nomor 40 Tahun 2007 Tentang Perseroan Terbatas," J. Priv. \& Com. L 1, No. 1 (2017): 111-132, https://doi.org/10.15294/jpcl.v1i1.12358, hlm. 121122.
} 
Penelitian sebelumnya terkait CSR telah dilakukan oleh Fahrial, Andrew S. Utama, dan Sandra Dewi pada tahun 2019 mengenai pemanfaatan CSR terhadap pembangunan perekonomian desa di Provinsi Riau15; Dani Amran Hakim, Agus Hermanto, dan Arif Fikri pada tahun 2019 mengenai kebijakan Pemerintah Daerah Provinsi Lampung terhadap CSR pada perusahaan ${ }^{16}$; Muhammad Iqbal dan Tahlim Sudaryanto pada tahun 2016 mengenai CSR dalam perspektif kebijakan pertanian $^{17}$; Sunaryo pada tahun 2013 mengenai CSR dalam perspektif pembangunan berkelanjutan ${ }^{18}$; dan Jamin Ginting pada tahun 2007 terkait tinjauan hukum CSR dalam Good Corporate Governance. ${ }^{19}$ Berdasarkan penelitian sebelumnya, walaupun memiliki kesamaan tema yaitu mengenai CSR, namun pada penelitian kali ini lebih berfokus pada kebijakan CSR di Indonesia sebagai upaya pemberdayaan masyarakat. Penelitian ini bertujuan untuk mengetahui kebijakan pengaturan tanggung jawab sosial dan lingkungan oleh perusahaan di Indonesia sebagai strategi pemberdayaan masyarakat.

\section{B. METODE PENELITIAN}

Penelitian ini bersifat deskriptif dengan jenis penelitian yuridis normatif. Jenis pendekatan yang digunakan adalah pendekatan peraturan perundangundangan dan pendekatan konseptual. Pendekatan perundang-undangan merupakan pendekatan yang mengacu pada ketentuan peraturan perundangundangan seperti Undang-Undang Nomor 40 Tahun 2007 tentang Perseroan Terbatas, Undang-Undang Nomor 25 Tahun 2007 tentang Penanaman Modal, Peraturan Pemerintah Nomor 47 Tahun 2012 tentang Tanggung Jawab Sosial dan Lingkungan Perseroan Terbatas, serta peraturan lainnya. Pendekatan

15 Fahrial, Andrew Shandy Utama, dan Sandra Dewi, "Pemamfaatan Corporate Social Responsibility (CSR) Terhadap Pembangunan Perekonomian Desa," Jurnal Wawasan Yuridika 3, No. 2, (2019): 251264, http://dx.doi.org/10.25072/jwy.v3i2.256, hlm. 253.

16 Dani Amran Hakim, Agus Hermanto, dan Arif Fikri, "Kebijakan Yuridis Pemerintah Daerah Terhdap Tanggung Jawab Sosial Perusahaan (Corporate Social Responsibility)," Jurnal Mahkamah: Kajian Ilmu Hukum Dan Hukum Islam 4, No. 2 (2019): 245-266, https://doi.org/10.25217/jm.v4i2.527 , hlm. 251.

17 Muhammad Iqbal dan Tahlim Sudaryanto, "Tanggung jawab Sosial Perusahaan (Corporate Social Responsibility) dalam Perspektif Kebijakan Pembangunan Pertanian," Analisis Kebijakan Pertanian 6, No. 2 (2016): 155-173, http://dx.doi.org/10.21082/akp.v6n2.2008.155-173, hlm. 162.

18 Sunaryo, "Corporate social Responsibility (CSR) Dalam Perspektif Pembangunan Berkelanjutan," Fiat Justitia Jurnal Ilmu Hukum 7, No. 1 (2013): 264-276, https://doi.org/10.25041/fiatjustisia.v7no1.363, hlm. 169.

19 Jamin Ginting, “Tinjauan Yuridis Terhadap Corporate Social Responsibility (CSR) Dalam Good Corporate Governance (GCG)," Lex Jurnalica 5, No. 1 (2007): 38-46, https://ejurnal.esaunggul.ac.id/ index.php/Lex/article/view/273, hlm. 38-40. 
konseptual merupakan pendekatan yang digunakan untuk memahami teori dan konsep-konsep yang dapat dijadikan landasan penelitian ini. Data yang digunakan pada penelitian ini adalah data sekunder yang terbagi atas bahan hukum primer, bahan hukum sekunder, dan bahan hukum tersier. Data sekunder tersebut diperoleh melalui teknik pengumpulan studi kepustakaan (library research), yang kemudian data dianalisis secara kualitatif.

\section{HASIL DAN PEMBAHASAN \\ 1. Kerangka Hukum Pengaturan CSR di Indonesia}

Kajian CSR sudah muncul sejak abad ke-20 atau sekitar tahun 1970-an di masyarakat barat (Eropa dan Amerika). Kemunculan konsep CSR menimbulkan perdebatan di kalangan ahli antara perlunya konsep CSR dilakukan langsung oleh perusahaan ataupun hanya dilaksanakan oleh pemerintah, perusahaan hanya bertanggung jawab kepada pemerintah. ${ }^{20}$ Kemudian berkembang, menjadikan kajian mengenai konsep CSR sebagai konsep yang memberikan perhatian lebih oleh perusahaan sebagai tanggung jawabnya terhadap sistem sosial. Setiap keputusan yang telah dibuat dan dilaksanakan oleh perusahaan perlu memperhatikan kepentingan sosial masyarakat dan lingkungan sekitarnya. ${ }^{21}$

Terdapat 3 (tiga) faktor yang menjadi latar belakang kemunculan CSR dalam perspektif barat. Kemunculan faktorfaktor tersebut sebenarnya bermula dari sudut pandang masyarakat barat terhadap bisnis. Pandangannya, perusahaan hanya berusaha untuk mengumpulkan keuntungan dan mementingkan kepentingan diri, walaupun merugikan orang lain. Pandangan inilah yang kemudian menimbulkan masalah sosial yang berat seperti jurang ekonomi, banyaknya masyarakat miskin, persoalan sosial, dan diskriminasi lainnya. Hal ini menimbulkan reaksi yang luas dari masyarakat barat yang menghendaki bisnis tidak hanya mencari keuntungan, melainkan juga memberikan perhatian kepada lingkungan sekitar, beretika, serta bersifat sosial. ${ }^{22}$

Tiga faktor yang dimaksud di atas adalah: pertama, kemunculan konsep CSR dalam masyarakat barat adalah ketika bermunculan berbagai industri setelah Perang Dunia II. Industri-industri mengambil SDA (seperti batubara, bijih besi) dalam jumlah sangat besar

\footnotetext{
20 Archie B. Carroll, “Corporate Social Resposibility: Evolution of a Definitional Construct,” Business $\mathcal{E}$ Society 38, No. 3 (1999): 268-295, hlm. 268.

21 Muhammad Yasir Yusuf, op.cit., hlm. 27.

$22 \quad$ Ibid., hlm. 32.
} 
sehingga meninggalkan efek buruk pada alam sekitar akibat eksplorasi SDA tanpa batas. Atas kejadian ini, masyarakat mulai memberikan perhatian serius terhadap cara baru dalam pembangunan ekonomi dengan memperhatikan alam sekitar; kedua, ketidakpuasan masyarakat terhadap perusahaan-perusahaan yang melakukan bisnis yang tidak beretika. Akibatnya, perusahaan kehilangan kepercayaan publik, khususnya masyarakat barat kala itu; dan ketiga, perhatian terhadap CSR mulai muncul dalam diskusi publik disebabkan peningkatan masalah sosial, seperti kemiskinan, pengangguran, gender, diskriminasi agama, serta pencemaran lingkungan dari pabrik-pabrik besar. John H. Dunning pada tahun 2003 dalam bukunya yang berjudul "The Moral Imperatives of Global Capitalism: An Overview" menyebutkan masalahmasalah sosial ini muncul karena efek globalisasi ekonomi, revolusi teknologi, serta perubahan demografi dan politik. ${ }^{23}$

Perhatian terhadap masalah alam sekitar dan adanya tekanan dari masyarakat yang dituangkan melalui peraturan perundang-undangan telah mengubah cara masyarakat dalam menjalankan bisnis. Keinginan untuk menjamin pembangunan yang berkelanjutan (sustainable development) membawa pada pembahasan yang luas mengenai konsep CSR. Upaya-upaya praktikCSR dari perusahaan-perusahaan dewasa ini didasarkan atas beberapa alasan. Pertama, adanya desakan dan tekanan pasar dari para pengguna, pekerja, ataupun pasar modal terhadap pilihan dalam menggunakan produkproduk perusahaan yang mempunyai CSR. Kedua, tumbuhnya kekuatan dan pengaruh media sosial yang mendorong konsumen membentuk organisasi. Peran organisasi dapat menekan perusahaan untuk melakukan aktivitas sosial terhadap masyarakat. Ketiga, secara sadar perusahaan meyakini bahwa tanggung jawab sosial yang dilakukan akan memberikan kesan positif yang baik bagi masyarakat dan pemegang kepentingan lainnya. Keempat, adanya tekanan dari peraturan perundang-undangan dan pemerintah untuk melakukan kegiatan CSR. ${ }^{24}$

Di Indonesia, penerapan CSR telah memperoleh landasan hukum berupa peraturan perundang-undangan terkait CSR. ${ }^{25}$ Peraturan perundang-undangan yang dimaksud adalah:

a. Undang-Undang Dasar Negara Republik Indonesia 1945, yaitu pada Pasal 28H ayat (1) yang menyebutkan

23 John H. Dunning dalam Ibid., hlm. 32-33.

24 Ibid.

25 Sunaryo, op.cit., hlm. 267. 
“...setiap orang berhak hidup sejahtera lahir dan batin, bertempat tinggal, dan mendapatkan lingkungan hidup yang baik dan sehat serta berhak memperoleh pelayanan kesehatan...". Kemudian pada Pasal 33 ayat (3) dan (4) yang menyatakan "...bumi dan air dan kekayaan alam yang terkandung di dalamnya dikuasai oleh negara dan dipergunakan untuk sebesar-besar kemakmuran rakyat. Perekonomian nasional diselenggarakan berdasar atas demokrasi ekonomi dengan prinsip kebersamaan, efisiensi berkeadilan, berkelanjutan, berwawasan lingkungan, kemandirian, serta dengan menjaga keseimbangan kemajuan dan kesatuan ekonomi nasional...";

b. Undang-Undang Nomor 5 Tahun 1990 tentang Konservasi Sumber Daya Alam Hayati dan Ekosistemnya, yaitu pada Pasal 6-10, Pasal 26-35, serta Pasal 37-38. Ketentuan ini terkait pemanfaatan dan konservasi SDA hayati serta ekosistemnya, kawasan pelestarian alam, sistem penyangga kehidupan, serta ketentuan lain yang terkait dengan konservasi sumber daya hayati serta ekosistemnya;

c. Undang-Undang Nomor 39 Tahun 1999 tentang Hak Asasi Manusia, yakni pada Pasal 9 ayat (3) yang menyebutkan “...setiap orang berhak atas lingkungan hidup yang baik dan sehat...";

d. Undang-Undang Nomor 41 Tahun 1999 tentang Kehutanan, yang terdapat pada Pasal 11-12, Pasal 20-51, dan Pasal 67-70. Ketentuan ini dikhususkan pada pengelolaan hutan di Indonesia, termasuk di dalamnya mengenai tata hutan, rencana pengelolaan, pemanfaatan dan penggunaan kawasan hutan, perizinan usaha hutan, perlindungan hutan dan konservasi alam, serta hak-hak masyarakat adat sekitar hutan ${ }^{26}$;

e. Undang-Undang Nomor 19 Tahun 2003 tentang Badan Usaha Milik Negara, yang terdapat pada Pasal 88 yang menyebutkan "...BUMN dapat menyisihkan sebagian laba bersihnya untuk keperluan pembinaan usaha kecil/koperasi serta pembinaan masyarakat sekitar BUMN...";

f. Undang-Undang Nomor 7 Tahun 2004 tentang Sumber Daya Air, yang terdapat pada Pasal 5-9, Pasal 11-12, Pasal 20-25, serta pada Pasal 59-62. Ketentuan ini terkait pengelolaan sumber daya air, pola pengelolaan, hak guna air, hak guna pakai air, hak guna usaha air, serta aturan lainnya yang berhubungan dengan sumber daya air;

$26 \quad$ Ibid., hlm. 268. 
g. Undang-Undang Nomor 25 Tahun 2007 tentang Penanaman Modal, yang terdapat pada Pasal 15 hingga Pasal 17. Ketentuan ini mengatur penanam modal wajib melaksanakan CSR dan menjaga kelestarian lingkungan hidup sekitar. Kemudian, bagi penanam modal wajib ikut serta mengalokasikan dana secara bertahap untuk pemulihan lokasi yang memenuhi standar kelayakan lingkungan hidup;

h. Undang-Undang Nomor 40 Tahun 2007 tentang Perseroan Terbatas, yang terdapat dalam Pasal 74 yang mengatur kewajiban melaksanakan tanggung jawab sosial serta lingkungan oleh Perseroan Terbatas (PT) atas kegiatan usahanya. Ketentuan lebih lanjut mengenai CSR ini diatur dengan Peraturan Pemerintah (PP);

i. Undang-Undang Nomor 4 Tahun 2009 tentang Pertambangan Mineral dan Batubara, yang terdapat pada Pasal 36-73, Pasal 85-86, Pasal 95112, dan Pasal 134-138. Ketentuanketentuan tersebut mengatur penggolongan bahan-bahan galian, kuasa pertambangan, hubungan antara kuasa pertambangan dengan hak atas tanah, serta seluruh aturan lain yang berhubungan dengan masalah pertambangan ${ }^{27}$, dan izin usaha pertambangan. ${ }^{28}$;

j. Undang-Undang Nomor 32 Tahun 2009 tentang Perlindungan dan Pengelolaan Lingkungan Hidup, yang terdapat pada Pasal 36 sampai Pasal 57. Ketentuan tersebut mengatur pelestariaan fungsi lingkungan, pelestarian daya dukung, pelestarian daya tampung lingkungan hidup, serta perizinan usaha;

k. Peraturan Pemerintah Nomor 47 Tahun 2012 tentang Tanggung Jawab Sosial dan Lingkungan Perseroan Terbatas, yang secara garis besar mengatur pelaksanaan CSR oleh perseroan dalam menjalankan usahanya di bidang SDA berdasarkan UU yang dapat dilaksanakan di dalam, maupun di luar lingkungan perusahaan. Pelaksanaan CSR disusun berdasarkan "kepatuhan dan kewajaran" perseroan. ${ }^{29}$ Kepatuhan dan kewajaran tersebut adalah kebijakan perseroan melaksanakan CSR sesuai kemampuan dan potensi

27 Gunawan Widjaya dan Yeremia Ardi Pratama, Risiko Hukum \& Bisnis Perusahaan Tanpa CSR (Jakarta: Forum Sahabat, 2008), hlm. 102-103.

28 Sunaryo, op.cit., hlm. 268.

29 Detania Sukarja, "Kewenangan Pembentukan Peraturan Daerah Tentang Corporate Social Resposibility Oleh Pemerintah Daerah Dan Implikasinya Terhadap Iklim Penanaman Modal Di Daerah," Seminar Nasional Hukum Dan Sosial 2 (2018): 30-42, https://eproceeding.undiksha.ac.id/ index.php/SENAHIS/article/view/1608, hlm. 34. 
keuangan. Berdasarkan PP ini, pelaksanaan CSR dapat ditujukan ke internal perusahaan (shareholders) maupun ke eksternal perusahaan (stakeholders). Tidak ada penjelasan lebih lanjut menegenai sanksi, akan tetapi tetap mengusung subtansi yang sama sesuai ketentuan Pasal 74 ayat (3) UU Perseroan Terbatas.

1. Peraturan Menteri BUMN Nomor 4 Tahun 2007, yang terdapat pada Pasal 2, Pasal 5, dan Pasal 9. Ketentuan ini mengatur kewajiban BUMN membentuk unit kerja khusus yang menangani langsung masalah pembinaaan serta pemberdayaaan masyarakat dengan alokasi dana senilai $2 \%$ dari laba bersih;

Apabila peraturan perundangundangan di atas dianalisis lebih lanjut, maka dengan diaturnya hak atas lingkungan sebagai HAM dan diadopsinya prinsip sustainable development dan berwawasan lingkungan ke dalam UUD NRI 1945 menunjukkan bahwa UUD NRI 1945 telah bernuansa hijau atau lebih dikenal dengan green constitution. ${ }^{30}$ Atas dasar hal tersebut, maka program-program pembangunan termasuk pelaksanaan CSR oleh perusahaan harus selaras dengan prinsip sustainable development dan berwawasan lingkungan yang diamanatkan oleh "green constitution" atau UUD NRI 1945.

Kewajiban pelaksanaan CSR berdasarkan Peraturan Menteri BUMN Nomor 4 Tahun 2007, tidak hanya ditujukan pada perusahaan BUMN, melainkan juga bagi perusahaan swasta. Perusahaan swasta dan BUMN tidak bisa hanya berorientasi pada kepentingan keuntungan perusahaan atau shareholder saja, melainkan harus memperhatikan kepentingan stakeholder dan kepentingan lingkungan alam setempat.

Pelaksanaan CSR saat ini bukan hanya sekadar suatu tanggung jawab moral (responsibility), melainkan sudah merupakan kewajiban hukum (liability). Sebagai salah satu contoh, CSR dalam konteks penanaman modal tidak hanya diwajibkan bagi Perseroan Terbatas (PT), melainkan juga perusahaan perorangan dan badan usaha lainnya (CV dan Firma) yang melakukan penanaman modal. Dalam hal kewajiban CSR tersebut tidak dilaksanakan, UU No. 25 Tahun 2007 tentang Penanaman Modal menetapkan bentuk sanksi administratif berupa peringatan tertulis, pembatasan kegiatan usaha, pembekuan, atau pencabutan izin usaha. Begitu juga dengan UU No. 40 Tahun 2007 tentang Perseroan Terbatas, CSR tidak hanya sekadar responsibility, melainkan telah menjadi liability. Selain

\footnotetext{
30 Jimly Asshiddiqie, Green Cosntituin: Nuansa Hijau Undang-Undang Dasar Negara Republik Indonesia Tahun 1945 (Jakarta: RajaGrafindo Persada, 2010), hlm. 9.
} 
itu, UU ini mewajibkan PT untuk melakukan tanggung jawab sosial serta lingkungan, Pasal 74 ayat (3) UU ini juga mengatur sanksi bagi PT yang tidak melaksanakan kewajibannya.

Selain itu, menurut Sukarja Detania, kerangka pengaturan CSR di atas belum memberikan kepastian hukum. Hal ini disebabkan berbagai ketidakjelasan, sehingga menyebabkan peraturan belum diterapkan secara efektif. Adanya pengaturan CSR yang tidak jelas dan dapat dikatakan tidak tepat sasaran dapat "mereduksi" makna CSR itu sendiri sebagai sumbangan uang belaka oleh perusahaan. Disebutkan lebih lanjut, hal ini justru dapat menjadi mekanisme bagi perusahaan untuk menyamarkan, bahkan menggelapkan aktivitas perusahaan yang tidak bertanggung jawab serta merugikan lingkungan alam dan masyarakat. ${ }^{31}$

\section{CSR sebagai Strategi Hukum dalam Pemberdayaan Masyarakat}

Kebijakan CSR oleh perusahaan merupakan strategi hukum dalam meningkatkan pemberdayaan masyarakat. Pelaksanaan kebijakan CSR dapat dikategorikan ke dalam 3 (tiga) bentuk, yakni hubungan publik (public relation), yaitu bentuk usaha untuk menanam persepsi positif kepada stakeholders atau pemamngku kepentingan tentang kegiatan yang dilakukan oleh perusahaan dengan menjalin hubungan yang sudah ada. Contohnya adalah mengampanyekan hal yang tidak terkait dengan produk yang dihasilkan oleh perusahaan itu sendiri; strategi pertahanan kedudukan (defensive), yaitu bentuk yang menjalin hubungan dengan proses melawan kejadian yang pernah dialami. Contohnya ada persepsi negatif dari stakeholders terhadap perusahaan, kemudian perusahaan melaksanakan CSR untuk mengubah persepsi negatif yang telah berkembang sebelumnya; dan bentuk yang ketiga adalah keinginan tulus untuk melakukan kegiatan yang baik dan benar-benar berasal dari visi serta misi perusahaan. ${ }^{32}$

Seperti disebutkan sebelumnya bahwa pelaksanaan CSR oleh perusahaan didasari oleh beberapa alasan. Sebagai contoh, pelaksanaan CSR karena adanya desakan dan tekanan pasar dari para pengguna, pekerja, ataupun pasar modal terhadap pilihan dalam menggunakan produk-produk perusahaan yang mempunyai CSR; adanya peran organisasi melalui media sosial yang dapat menekan perusahaan melakukan aktivitas sosial terhadap masyarakat; secara sadar perusahaan

31 Detania Sukarja, op.cit., hlm. 38.

32 Budi Gautama Siregar, op.cit., hlm. 145. 
meyakini bahwa CSR yang dilakukan akan memberikan kesan positif yang baik bagi stakeholders; dan adanya tekanan dari peraturan perundang-undangan untuk melakukan kegiatan CSR. ${ }^{33}$

Atas dasar adanya tekanan dari peraturan perundang-undangan terhadap perusahaan agar melaksanakan kegiatanCSR, merupakan strategihukum untuk dapat melindungi kepentingan masyarakat. Selain itu, adanya CSR dapat membantu pemerintah untuk menangani keterbatasan anggaran dalam membangun sosial ekonomi kawasan perusahaan, secara holistik, melembaga, serta berkelanjutan. ${ }^{34}$ Adanya kemitraan antara pemerintah serta perusahaan tersebut tidak lain diperlukan untuk upaya peningkatan kesejahteraan masyarakat, baik melalui program-program peningkatan kualitas infrastruktur seperti perbaikan jalan rusak ataupun program-program terkait pemberdayaan masyarakat.

Pemberdayaan (empowerment) berasal dari kata "power" (keberdayaan atau kekuasaan). Secara konseptual, pemberdayaan bersentuhan langsung dengan konsep kekuasaan. Kekuasaan atau keberdayaan sering kali dikaitkan dengan kemampuan untuk membuat orang lain melakukan apa yang diinginkan. Dengan kata lain, pemberdayaan memiliki tujuan untuk meningkatkan kekuasaan orang-orang yang lemah dan tidak beruntung. Terdapat 3 (tiga) strategi pembedayaan, yaitu strategi pemberdayaan politik yang bertujuan untuk diarahkan pada upaya membangkitkan kesadaran kritis masyarakat, sehingga mereka lebih tanggap terhadap persoalan maupun kebijakan yang sebenarnya yang dapat merugikan mereka; strategi pemberdayaan sosial yaitu strategi yang terkait dengan bagaimana upaya yang dilakukan untuk memberikan perlindungan terhadap masyarakat, kebutuhan-kebutuhan masyarakat di bidang sosial, serta meningkatkan solidaritas masyarakat; dan strategi pemberdayaan ekonomi yaitu strategi untuk menumbuhkan tingkat pendapatan masyarakat. ${ }^{35}$

Pemberdayaan masyarakat di atas pada dasarnya dapat dilaksanakan dengan adanya konsep atau kebijakan program-program CSR oleh perusahaan. Adanya pemberdayaan masyarakat melalui program-program

33 Muhammad Yasir Yusuf, op.cit., hlm. 33.

34 Rahmatullah, op.cit., hlm. 41-42.

35 Safri Miradj, dan Sumarno, "Pemberdayaan Masyarakat Miskin, Melalui Proses Pendidikan Nonformal, Upaya Meningkatkan Kesejahteraan Sosial DiKabupaten Halmahera Barat," Jurnal Pendidikan Dan Pemberdayaan Masyarakat 1, No. 1 (2014): 101-112, https://doi.org/10.21831/jppm. v1i1.2360, hlm. 109-110. 
CSR dimaksudkan untuk mengatasi permasalahan kemiskinan masyarakat. ${ }^{36}$ Kemiskinan merupakan permasalahan mendasar yang terjadi pada masyarakat yang harus diselesaikan. Penanggulangan kemiskinan ini harus dilakukan secara strategis, sistematis, serta menyeluruh agar seluruh masyarakat dapat menikmati kehidupan yang bermartabat. Dapat dikatakan persoalan kemiskinan bukan hanya berdimensi ekonomi semata, melainkan juga pada dimensi politik, pendidikan, dan dimensi sosial. Selama ini, banyak program penanggulangan kemiskinan yang dilaksanakan pemerintah masih terasa belum maksimal, sehingga membutuhkan dorongan dari programprogram CSR perusahaan.

\section{Kebijakan}

program-program CSR sebagai strategi hukum dalam mendukung pemberdayaan masyarakat dapat berupa program pendidikan gratis, baik pendidikan non formal maupun pendidikan formal. Dalam mempertahankan kelangsungan, perusahaan tidak hanya memaksimalkan laba yang diperolehnya, melainkan diperlukan juga sebuah tanggung jawab sosial berupa kewajiban terhadap stakeholders di bidang pendidikan. Selain meningkatkan citra baik perusahaan, program pendidikan gratis ini merupakan tanggung jawab terhadap generasi bangsa; kemudian program pengembangan usaha lokal untuk membuka peluang usaha bagi masyarakat; program kepedulian berupa recruitment tenaga kerja lokal sebagai tenaga kerja; serta program-program lainnya. Jadi, program-program CSR terkait pemberdayaan di atas dapat dirasakan oleh masyarakat dalam kurun waktu yang lama (manfaat jangka panjang). Berbeda dengan program CSR yang sifatnya sementara seperti bantuan makanan atau sembako, bantuan minuman, pemberian bahan bakar, perbaikan jalan rusak, serta program CSR lainnya yang manfaatnya hanya dirasakan secara singkat. ${ }^{37}$

Adanya kebijakan program-program CSR terkait pemberdayaan masyarakat seperti pendidikan dapat memberikan kontribusi bagi tujuan pembangunan berkelanjutan, di mana konsep CSR dapat mewujudkan masyarakat yang makmur serta sejahtera, baik secara individual dan secara sosial. Pentingnya pendidikan, baik formal dan non formal dapat mendorong masyarakat untuk terus berperan aktif dalam merespon pembangunan yang berkelanjutan.

\footnotetext{
36 Andrew Shandy Utama, dan Rizana, “Implementasi Corporate Social Responsibility PT Riau Crumb Rubber Factory Terhadap Masayarakat Kelurahan Sri Meranti Kota Pekanbaru," Jurnal Hukum Novelty 8, No. 2, (2017): 173-186, http://dx.doi.org/10.26555/novelty.v8i2.a6884, hlm. 182.

37 Bambang Rudito, dan Melia Famiola, Corporate Social Responsibility (CSR) (Bandung: Rekayasa Sains, 2019), hlm. 103-104.
} 


\section{SIMPULAN}

Keberadaan konsep CSR atau tanggung jawab sosial serta lingkungan di Indonesia telah memperoleh legitimasi untuk dilaksanakan oleh perusahaan swasta dan BUMN. CSR bukan hanya sekadar responsibility (tanggung jawab moral), melainkan sudah menjadi liability (tanggung jawab hukum), karena kewajiban serta sanksi terkait CSR telah diatur dalam berbagai peraturan perundang-undangan, baik yang terkait dengan HAM maupun yang berhubungan dengan perusahaan. Pemberdayaan masyarakat dapat dilaksanakan melalui kebijakan program-program CSR oleh perusahaan. Adanya pemberdayaan masyarakat melalui kebijakan program-program CSR merupakan starategi hukum untuk mengatasi permasalahan kemiskinan masyarakat. Kebijakan programprogram CSR terkait pemberdayaan masyarakat dapat berupa program pendidikan gratis, baik pendidikan non formal dan pendidikan formal; kemudian program pengembangan usaha lokal untuk membuka peluang usaha bagi masyarakat; program kepedulian berupa recruitment tenaga kerja lokal sebagai tenaga kerja; serta program-program lainnya. Adanya program-program CSR terkait pemberdayaan masyarakat seperti pendidikan dapat memberikan kontribusi bagi tujuan pembangunan berkelanjutan, di mana konsep CSR dapat mewujudkan masyarakat yang makmur dan sejahtera, baik secara individual dan secara sosial.

\section{DAFTAR PUSTAKA}

Asshiddiqie, Jimly. Green Cosntituin: Nuansa Hijau Undang-Undang Dasar Negara Republik Indonesia Tahun 1945. Jakarta: RajaGrafindo Persada. 2010.

Carroll, Archie B. "Corporate Social Resposibility: Evolution of a Definitional Construct." Business $\mathcal{E}$ Society 38, No. 3 (1999): 268-295.

Fahrial, Andrew Shandy Utama, dan Sandra Dewi. "Pemamfaatan Corporate Social Responsibility (CSR) Terhadap Pembangunan Perekonomian Desa." Jurnal Wawasan Yuridika 3, No. 2 (2019): 251-264. http://dx.doi.org/10.25072/jwy. v3i2.256.

Ginting, Jamin, “Tinjauan Yuridis Terhadap Corporate Social Responsibility (CSR) Dalam Good Corporate Governance (GCG)." Lex Jurnalica 5, No. 1 (2007): 38-46. https:// ejurnal.esaunggul.ac.id/index.php/ Lex/article/view/273 .

Hakim, Dani Amran, Agus Hermanto, dan Arif Fikri. "Kebijakan Yuridis Pemerintah Daerah Terhdap Tanggung Jawan Sosial Perusahaan (Corporate Social Responsibility)." Jurnal Mahkamah: Kajian Ilmu Hukum Dan Hukum Islam 4, No. 2 (2019): 245-266. https://doi.org/10.25217/ jm.v4i2.527. 
Iqbal, Muhammad, dan Tahlim Sudaryanto. "Tanggungjawab Sosial Perusahaan (Corporate Social Responsibility) dalam Perspektif Kebijakan Pembangunan Pertanian." Analisis Kebijakan Pertanian 6, No. 2 (2016): 155-173. http://dx.doi. org/10.21082/akp.v6n2.2008.155-173.

Kashyap, Rajiv, Raza Mir, dan Ali Mir. "Corporate Social Responsibility: A Call For Multidisciplinary Inquiry." Journal of Business \& Economics Research 2, No. 7 (2004): 51-58. https:// doi.org/10.19030/jber.v2i7.2902.

Marthin, Marthen B., Salinding, dan Inggit Akim. "Implementasi Prinsip Corporate Social Responsibility (CSR) Berdasarkan Undang-Undang Nomor 40 Tahun 2007 Tentang Perseroan Terbatas." J. Priv. \& Com. L 1, No. 1 (2017): 111-132. https://doi. org/10.15294/jpcl.v1i1.12358.

Miradj, Safri, dan Sumarno. "Pemberdayaan Masyarakat Miskin, Melalui Proses Pendidikan Nonformal, Upaya Meningkatkan Kesejahteraan Sosial Di Kabupaten Halmahera Barat." Jurnal Pendidikan Dan Pemberdayaan Masyarakat 1, No. 1 (2014): 101-112. https://doi. org/10.21831/jppm.v1i1.2360.

Rahmatullah. "Model Kemitraan Pemerintah Dengan Perusahaan Dalam Mengelola CSR: Studi Kasus Di Kota Cilegon." Sosio Informa
17, No. 1 (2012): 36-47. https:// ejournal.kemsos.go.id/index.php/ Sosioinforma/article/view/66/36.

Rudito, Bambang, dan Melia Famiola. Corporate Social Responsibility (CSR). Bandung: Rekayasa Sains. 2019.

Siregar, Budi Gautama. "Penerapan Corporate Social Responsibility (CSR) Dalam Pandangan Islam." Juris 14, No. 2 (2015): 135-150. http:// dx.doi.org/10.31958/juris.v14i2.303.

Sukarja, Detania. "Kewenangan Pembentukan Peraturan Daerah Tentang Corporate Social Resposibility oleh Pemerintah Daerah dan Implikasinya Terhadap Iklim Penanaman Modal Di Daerah." Seminar Nasional Hukum Dan Sosial 2 (2018): 30-42. https:// eproceeding.undiksha.ac.id/index. php/SENAHIS/article/view/1608.

Sunaryo. "Corporate Social Responsibility (CSR) Dalam Perspektif Pembangunan Berkelanjutan." Fiat Justitia Jurnal Ilmu Hukum 7, No. 1 (2013): 264-276. https://doi. org/10.25041/fiatjustisia.v7no1.363.

Syahputra, Erwin, dan Suteki. "Strategi Baru Pengentasan Kemiskinan Melalui Hukum Sebagai Sarana Pemberdayaan Corporate Social Responsibility." Masalah-Masalah Hukum 46, No. 1 (2017): 1-8. https:// doi.org/10.14710/mmh.46.1.2017.1-8. 
Utama, Andrew Shandy, dan Rizana. "Implementasi Corporate Social Responsibility PT Riau Crumb Rubber Factory Terhadap Masayarakat Kelurahan Sri Meranti Kota Pekanbaru." Jurnal Hukum Novelty 8, No. 2 (2017): 173-186. http://dx.doi.org/10.26555/novelty. v8i2.a6884.

Wahyuningrum, Yuniarti, Irwan Noor, dan Abdul Wachid. "Pengaruh Program Corporate Social Responsibility Terhadap Peningkatan Pemberdayaan Masyarakat (Studi Pada Implementasi CSR PT. Amerta Indah Otsuka Desa Pacarkeling Kecamatan Kejayan Kabupaten Pasuruan)." Jurnal Administrasi Publik (JAP) 1, No. 5 (2014): 109-115. http:// administrasipublik.studentjournal. ub.ac.id/index.php/jap/article/ view/340.

Widjaya, Gunawan, dan Yeremia Ardi Pratama. Risiko Hukum \& Bisnis Perusahaan Tanpa CSR. Jakarta: Forum Sahabat. 2008.

Yusuf, Muhammad Yasir. Islamic Corporate Social Responsibility (I-CSR) Pada Lembaga Keuangan Syariah (LKS).

Depok: Kencana. 2017. 